\title{
Expression of Justice or Political Trial? Discursive Battles in the Karadžić Case
}

\author{
Tim Meijers $^{\#} \&$ Marlies Glasius ${ }^{*}$
}

\author{
PRE-EDITED VERSION OF: \\ Meijers, Tim and Glasius, M. (2013) 'Expression of Justice or Political Trial? Discursive Battles in the \\ Karadžić Case', Human Rights Quarterly, 35 (3), in press.
}

\begin{abstract}
$^{1}$
This article examines the discourses of prosecution and defense in the case of Radovan Karadžić before the International Criminal Tribunal for the former Yugoslavia. It focuses on what happens in the courtroom - a site mostly neglected in the literature on transitional justice - and the consequences courtroom discourses may have for societies in transition. Our theoretical point of departure is the concept of 'expressivism', which is an attempt to theorize courts' potential to send messages as a key feature in thinking about the relationship between normative legitimacy, support and utility of international trials. We conclude that the defense by Karadžić disrupts and thwarts the pedagogical messaging intended by expressivism to a considerable extent, and reflect on the generalizability of our findings by considering the elements of the actors, audiences, and the stage in the posited "courtroom drama."
\end{abstract}

\footnotetext{
\# Tim Meijers is a Ph.D. student (Fonds de la Recherche en Sciences Humaines, Belgium) in Political Philosophy at the Hoover Chair of economic and social ethics, Université Catholique de Louvain (Louvain-laNeuve), earlier he worked as a research-assistant at the University of Amsterdam. Among his research interests are international (criminal) justice, intergenerational justice, population ethics and the implications of political philosophy for public policy. His MSc-thesis Legitimacy, Citizenship and International Criminal Courts (2009) was awarded the J.C. Baakprize (Royal Dutch Academy for the Sciences). He has recently published a paper in The International Journal of Transitional Justice and Human Rights Quarterly. He is currently working on his thesis, focusing on the relation between theories of justice and population ethics.

* Marlies Glasius is a Professor in International Relations at the Department of Politics, University of Amsterdam and IKV Special Chair in Citizen Action in Conflict and Post-Conflict Situations, Free University, Amsterdam. In 2012 she was a Fellow at the Netherlands Institute of Advanced Studies (NIAS) in Wassenaar and Visiting Professor at the Université Catholique de Louvain. Her research interests include the theory and practice of global civil society, international criminal justice, human security and authoritarian rule. She is the author of The International Criminal Court: A Global Civil Society Achievement (2006) and recent articles on international criminal justice in African Affairs, European Journal of International Law and International Journal of Transitional Justice.

${ }^{1}$ We wish to thank the Dutch Science Foundation NWO for its financial support to the 'Constructions of Justice' project. Tim Meijers acknowledges the support of FRESH (Fonds de la Recherche en Sciences Humaines) and the ARC (French-speaking community of Belgium, project 09/14-018). We thank our colleagues at the UvA and at NIAS for their comments on an earlier draft of this article.
} 


\title{
I. Introduction
}

On one reading, the International Criminal Tribunal for the Former Yugoslavia (ICTY) has triumphed in its closing days. In 2011, it has completed its most high-profile Croatian trial, against General Ante Gotovina, caught Bosnian Serb General Ratko Mladić and soon afterwards Goran Hadžić, the tribunal's final indictee at large. The ICTY itself subscribes to such an optimistic reading. In a brochure and on its website, it lists "strengthening the rule of law," "establishing the facts," "giving victims a voice" and "bringing justice to the victims,"2 not among its aims but among its achievements. The 300 million $^{3}$ dollar per annum budget of the ICTY is justified by the claim that it "is an investment in the peace and future of south-eastern Europe." Former president of the court Antonio Cassese has asserted that:

\begin{abstract}
"Justice is an indispensable ingredient of the process of national reconciliation. It is essential to the restoration of peaceful and normal relations between people who have lived under a reign of terror. It breaks the cycle of violence, hatred and extra-judicial retribution. Thus peace and justice go hand in hand."4
\end{abstract}

Social scientists who have set out to test such claims have come to rather different conclusions. Public opinion surveys and qualitative research in the former Yugoslavia consistently show either outright hostility or disappointment to be the dominant attitudes towards the tribunal. ${ }^{5}$ Scholars have argued that the ICTY has not done enough to reach out to the societies on which it adjudicates, ${ }^{6}$ that it did not do enough to counter negative

\footnotetext{
${ }^{2}$ See Marlies Glasius and Francesco Colona (2013). 'The Yugoslavia Tribunal: The Moving Targets of a Legal Theatre', in Dino Abazovic and Mitya Velikonya (eds). Otherhood and Disunity: Social and Political Struggles in Southeastern Europe (Houndmills, Basingstoke: Palgrave Macmillan) for a discussion of these 'achievements'.

${ }^{3}$ See ITCY, Budget 2010-2011, available at http://www.icty.org/sid/325.

${ }^{4}$ Antonio Cassese, cited in the banner of the ICTY website, available at http://www.icty.org/sid/3.

${ }^{5}$ For a discussion of local support for the ICTY see Sanja Kutnjak Ivković \& John Hagan, Reclaiming Justice: the International Tribunal for the former Yugoslavia and Local Courts, at ch. 2 (2011). See also Dan Saxon, Exporting Justice, Perceptions of the ICTY Among the Serbian, Croatian and Muslim Communities in the Former Yugoslavia, 4 J. HuM. RTS. 559 (2005).

${ }^{6}$ Donna Arzt, Views on the Ground, The Local Perception of the International Criminal Tribunals in the Former Yugoslavia and Sierra Leone, 603 ANNALS OF THE AAPPS 226 (2007); Michael P. Scharf \& Ahran Kang, Errors and Missteps: Key Lessons the Iraqi Special Tribunal Can Learn from the ICTY, ICTR and
} 
propaganda in the local press, ${ }^{7}$ and that it may have distorted a smooth political transition. ${ }^{8}$ Other international criminal tribunals such as the International Criminal Tribunal for Rwanda, the Special Court for Sierra Leone and the International Criminal Court have encountered very similar criticisms. ${ }^{9}$

We take a step back from these debates and ask a prior question. Instead of asking "How well have international criminal tribunals succeeded in fulfilling socio-political aims such as providing a historical record, restoring the rule of law, giving justice to victims or reconciling communities"? we ask "How are international criminal tribunals supposed to fulfil such aims?" In other words, we try to understand through what kind of mechanism international criminal courts are supposed to reach such goals. The mechanisms through which international criminal courts can disseminate certain values and contribute to a better society have largely been neglected in the literature in transitional justice. And as seen above, international criminal courts themselves assert that they realize certain socio-political objectives through trial justice without having a clear explanation how they are realizing these effects. This paper aims to address a part of this important question. ${ }^{10}$

Moreover, while the legal literature on international criminal courts neglects political context, the social science literature curiously neglects detailed analysis of what happens inside the courtroom. ${ }^{11}$ More particularly, it has failed to attribute effects to the role of the defendant in the courtroom, despite the fact that the trials of high-profile defendants like Slobodan Milosevic, Charles Taylor, Radovan Karadžić and now Kenyan presidential

SCSL, 38 CORnell InT'L L. J. 911 (2005); Macdonald, Gabrielle Kirk McDonald, Problems, Obstacles and Achievements of the ICTY, 2 J. INT'L CRIM. JUSTICE 558 (2004).

${ }^{7}$ Mirko Klarin, The Impact of the ICTY Trials on Public Opinion in the Former Yugoslavia, 7 J. INT'L CRIM. JUSTICE 89 (2009).

${ }^{8}$ Marlene Spoerri \& Annette Freyberg-Inan, From Persecution to Prosecution: Perceptions of the ICTY in Serbian Domestic Politics, 11 J. InT'L Relations \& DEV. 250 (2008).

${ }^{9}$ See Scharf \& Kang, supra note 6; Marlies Glasius, 'Do International Criminal Courts Require Democratic Legitimacy?', 23 EJIL 1 (2012).

10 See Marlies Glasius \& Tim Meijers, Constructions of Legitimacy: The Charles Taylor Trial, International Journal of Transitional Justice 6 (2) (2012), 229-252, for a very different case study addressing the same question.

${ }^{11}$ Significant exceptions are Tim Kelsall, Culture under Cross-Examination: International Justice and the Special Court for Sierra Leone (Cambridge University Press, Cambridge, 2009); Gerry J. Simpson, Law, War and Crime: war crimes trials and the reinvention of international law (Polity Press, Cambridge, 2007), esp. pp. 54-78; Nancy A. Combs, Guilty Pleas in International Criminal Law: Constructing a Restorative Justice Approach, (Stanford University Press, Palo Alto, 2007). 
candidates Kenyatta and Ruto have been very much in the media spotlights. We posit that the (lack of) socio-political effectiveness of international criminal courts cannot be explained without also considering what happens in court during the trial.

In our attempt to theoretically link what happens inside the courtroom in international criminal trials to their potential effects outside, we will draw on the theory of legal expressivism, which has been applied to international criminal courts by Diane Amann andMark Drumbl. ${ }^{12}$ Drumbl holds that international criminal trials can be seen as educational dramas, which disseminate norms and values to audiences. We will elaborate on the claims made for international criminal trials by expressivism. Subsequently, we will undertake a discourse analysis of court transcripts in the trial of Radovan Karadžić as a point of departure for investigating the expressivist claims. Our aim is to arrive at a more elaborate and nuanced theory of the expressivist potential of international criminal trials.

The Karadžić trial lends itself particularly well to this purpose: he is arguably the most high-profile defendant after Milosevic, who died in detention before a sentence could be reached, and like Milosevic, he conducts his own defence. His trial, along with that of Ratko Mladić, is also one of the last before the ICTY is to close its doors. At the time of writing, the trial is still ongoing. On the one hand, this provides a challenge, as the discourses we examine could be considered "incomplete" until the end of the trial. On the other hand, we consider it as an advantage, since it focuses attention on the dynamic nature of the discursive battles in court, which typically take many years before the verdict, on which legal scholars almost exclusively focus, is reached. Our contention is that international criminal trials begin to "express" messages to audiences long before the verdict is out.

In the next section, we will discuss the theoretical framework at greater length, and spell out how a discourse analysis of prosecutor and defence speeches can contribute to formulating a more sophisticated version of the expressivist theory. In section 3 we briefly

\footnotetext{
${ }^{12}$ Marc Drumbl, Atrocity, Punishment and International Law (Cambridge, Cambridge University Press, 2007), Diane Amann, Assessing International Criminal Adjudication of Human Rights Atrocities, Third World Legal Studies), 16, 1(2003)
} 
set out the approach we have taken to discourse analysis. In section 4 we will discuss and compare the discourses of Karadžić and the prosecution on the nature of the Bosnian war and Karadžić' role in it, and in section 5 we will examine the discourses on the trial itself. In the section 6 we revisit the extent to which expressivism can help specify whether or how international criminal trials are supposed to achieve socio-political aims.

\section{Theoretical Points of Departure}

Elsewhere we have applied Buchanan and Keohane's distinction between normative and sociological legitimacy to international criminal courts. ${ }^{13}$ Normative legitimacy derives from the position that a court has moral authority to concern itself with the case in question. It may rely on backward-looking arguments such as retribution, accountability, or official truth-telling, or on forward-looking, consequentialist arguments such as preventive effects, reconciliation effects, and closure for victims or instilment of respect for the rule of law.

Sociological legitimacy, or acceptance of the authority of courts and their trials and verdicts, is an empirical question for the social scientist, and has many faces. A realist approach to sociological legitimacy would argue that the only relevant acceptance is that of powerful actors in international politics, who would accept and indeed support the Court for their own ends. A critical theory approach, paradoxically, would depart from the same assumption, but stress the discursive framework used to obscure and depoliticize such realities. A cosmopolitan approach would be to argue that the Court represents "the international community," or perhaps even "mankind," but would be likely to infer such acceptance on the basis of a normative argument, rather than taking global opinion polls. A communitarian approach would focus on acceptance by the population affected by the violent acts that are being adjudicated. A victim-centered approach, finally, would stress the acceptance by and utility value for the direct victims of the crimes in question ${ }^{14}$.

While many acknowledge the interconnection between normative and sociological

\footnotetext{
${ }^{13}$ Tim Meijers, 'Legitimacy, International Courts and Citizenship' (MA-Thesis, University of Amsterdam, 2010)

${ }^{14}$ These two paragraphs have been reproduced from our reflections on legitimacy in Glasius and Meijers, (2012) 231-232.
} 
legitimacy of international criminal courts, the "expressivist" doctrine gives us a rare tool to theorise this connection. Expressivism ${ }^{15}$ is a theory originating from normative legal theory, concerned with the function of law. It is, however, not a uniform approach. One branch of expressivism, following Durkheim, holds that the law simply is an expression of dominant moral attitudes in society. We will not use this conception of expressivism in this article. ${ }^{16}$ Another group of theorists hold that the law can be used to transform these moral attitudes ${ }^{17}$ (as a sociological claim) and yet a third group argues that this should be the function of the law $^{18}$ (which is a normative claim). As Sunstein points out, expressivists are interested in "how legal 'statements' might be designed to change social norms." 19 Our interest in this paper is in applying the second, empirical application of expressivism, but with an eye to the third, normative claim: our research is informed by the conviction that international criminal tribunals should attempt to have beneficial effects on societies in transition.

Many theorists working on expressivism are mainly concerned with the expressive value of the $l a w^{20}$ or of punishment, ${ }^{21}$ Instead, we focus on the expressivist potential of the trial itself, which according to one classic account can be seen as "status degradation ceremonies" to express "moral indignation.",22 This seems to be a particularly appropriate approach to international criminal trials, which typically take many years, may involve defendants who already have notoriety, and are often televised.

15 For a recent overview of debates in Expressivism see: Edwards, M. Legal Expressivism: A Primer, unpublished working paper(2009) http://papers.ssrn.com/sol3/papers.cfm?abstract id=1361101; For a defence see Anderson, E. S. And Pildes, R.H. Expressive Theories of Law: A General Restatement, University of Pennsylvania Law Review, 148, 5, pp. 1503-1576(2000).

${ }^{16}$ This division of expressivism follows, loosely, Edwards distinction between 'Instrumental' (use laws to change norms) and 'Revelatory' (laws express most fundamental normative committments) Expressivism. See Edwards (2005) supra. He does not, however, distinguish between the sociological and normative claim underlying instrumental expressivism.

${ }^{17}$ See Anderson and Pildes, supra note 13.

${ }^{18}$ Cass Sunstein, The Expressive Function of the Law, Univ. Pa. L. Rev. 144, pp. 2021(1995) advocates this view. He says that his 'principle aim is to defend laws that attempt to alter norms, rather than laws that merely 'speak',

${ }^{19}$ Sunstein supra, 2025.

${ }^{20}$ Funk, P. Is There an Expressive Function of Law? An empirical analysis of voting laws with symbolic fines, American Law Economics Review, Vol. 9, No. 1(2007); Sunstein, supra.

${ }^{21}$ Sloane, R.D. (2007) The Expressive Capacity of International Punishment: The Limits of the National Law Analogy and the Potential of International Criminal Law, in Stanford Journal of International Law, Vol. 39, 39; Feinberg, J. the expressive function of punishment, in Monist, Vol. 49, No. 3, p. 397(1965).

${ }^{22}$ Garfinkel, H. (1956) Conditions of Successful Degradation Ceremonies, in The American Journal of Sociology, 61, 5, 420 (March 1956). 
Two legal scholars, $\mathrm{Amann}^{23}$ and Drumbl, $^{24}$ have elaborated the claim that international criminal justice, while not very good at delivering deterrence or retribution, can be justified in terms of expressivist functions. According to Diane Amann, "( $t$ )heories of expressivism analyse the message of a governmental act, such as a prosecution or a sentence to punishment." 25 She shows how the judges at Nuremberg as well as the ICTY have often understood their own work in expressivist terms. Mark Drumbl's account is even more compelling and appropriate, since he specifies what we identified as a missing link between normative and sociological legitimacy: an account of how trials disseminate messages to audiences:

Trials can educate the public through the spectacle of theatre - there is, after all, pedagogical value to performance and communicative value to dramaturgy. This performance is made all the more weighty by the reality that, coincident with the closing act, comes the infliction of shame, sanction and stigma upon the antagonists. ${ }^{26}$

Drumbl in other words describes a mechanism through which, according to his assertion, international criminal trials are achieving socio-political aims. Amann, Drumbl and other expressivists give similar accounts of the typical content of the messages that can be conveyed by international criminal trials.

First and foremost, they are "a forum for making a historical record""27; "a central goal [is] the crafting of historical narratives, their authentication as truths, and their pedagogical dissemination to the public." ${ }^{28}$ Second, they "individuate guilt. They name as criminals identifiable individuals, rather than all members of a group. That individuation

\footnotetext{
${ }^{23}$ Amann, D. Assessing Criminal Adjudication of Human Rights Atrocities, Third World Legal Studies, 16, 1, 169 (2003).

${ }^{24}$ Drumbl, M. Atrocity, Punishment and International Law (Cambridge University Press, Cambridge, 2007).

${ }^{25}$ Amann,supra note 21, 176.

${ }^{26}$ Drumbl, 175.

${ }^{27}$ Amann, 175.

${ }^{28}$ Drumbl, 173.
} 
may help reconstruction by removing guilt from others." 29 This is also a function the ICTY has claimed to have achieved. ${ }^{30}$ Third, the trial provides "a forum for enunciating societal condemnation of atrocities," 31 or to put it more harshly, in the language of Drumbl quoted above, for inflicting shame and stigma on the perpetrators of massive crimes. Between them, establishment of the truth, individuation of guilt, and disapproval and stigmatization are to contribute to the general expressivist aim of norm-dissemination, strengthening the rule of law by invoking it. Finally, through the restoration of the rule of law, international criminal trials could conceivably contribute to reconciliation between communities. As seen above, Cassese has made this claim for the ICTY. ${ }^{32}$

We consider Drumbl's theatrical metaphor a useful one for understanding how international criminal trials may achieve social aims. The comparison of important trials to theatrical spectacle ("courtroom drama") is a common one, and particularly appropriate to high-profile cases like that of Radovan Karadžić, Slobodan Milosevic, Charles Taylor, JeanPierre Bemba, Laurent Gbagbo. But Drumbl's metaphor needs further elaboration in at least three respects. First, it overlooks one of the main ingredients of a drama: actors. More particularly, the role of the defendant is treated as a passive one. Our expectation on the contrary is that defendants may use the stage to destabilise the authentication of historical narratives, the individuation of guilt, and the infliction of shame and stigma that is supposed to follow. Second, there is the matter of audiences. Drumbl, while recognising that the "didactic value of international proceedings is not preordained," yet asserts that the expressivist function can and must be simultaneously achieved across different audiences, including "a global audience" as well as "the audience that matters more than any othernamely, directly afflicted populations." 33 Finally, in the transposition of expressivism from domestic to international criminal law, one important aspect may be missed: the extent to which, due to the new and precarious nature of international criminal institutions, and the

\footnotetext{
${ }^{29}$ Amann, 178; see als Minow, M. The Work of Re-Membering: After Genocide and Mass Atrocity, Fordham International Law Journal, at 430-431(1999) . This function has been critiqued, however, by Drumbl, 36 and others.

${ }^{30}$ ICTY website supra note 1.

${ }^{31}$ Amann, 175.

32 Amann, 175 on the other hand finds this claim 'somewhat breathtaking, and belied by the prolongation of conflict in the Balkans'.

${ }^{33}$ Drumbl, 175.
} 
political nature of the crimes themselves, the courts and their trials are themselves contentious, or to stretch a metaphor, "on trial," and the role this contention plays within the trial discourses.

Our intention in the remainder of this article is not to test current support for the ICTY or the Karadžić case with all or indeed any of its potential audiences. Instead, we will examine how legitimacy is constructed and challenged in the discourses of the prosecution and the defence in the Karadžić trial themselves. In doing so we seek to establish to what extent what is said and done in the Karadžić trial confirms or disrupt the potential expressivist functions of international criminal justice put forward above. Our aim is to provide an assessment of the promises and pitfalls of the expressivist account of the functions of international criminal law that draws on, but goes beyond the Karadžić case.

\section{Discourse analysis}

The approach to discourse analysis proposed here draws on critical linguistics and poststructuralism, but has a more functional orientation, focusing on what discourses are designed to accomplish. ${ }^{34}$ It is less concerned with ways in which social actors are themselves constituted by discourse, but instead concentrates on the constructive use of language, ${ }^{35}$ treating texts as organised rhetorically, establishing a particular version of social reality in competition with others. ${ }^{36}$

The main method of discourse analysis has been close textual analysis of court transcripts $^{37}$. We downloaded the court transcripts covering the period from Karadžić' first appearance in July 2008 until July 2011, covering approximately 15,000 pages. Since we were only interested in the discourses of the prosecution and the defendant, transcripts that dealt primarily with witness statements were excluded, except in cases where prosecution or

\footnotetext{
34 Rosalind Gill, 'Discourse Analysis', in: Martin Bauer and George Gaskell (eds) Qualitative Researching with Text, Image and Sound (Sage, Los Angeles, 2000), 173-174.

35 Jonathan Potter, et al., 'Discourse: Noun, Verb or Social Practice', Philosophical Psychology, 3, 2 205-217 (1990).

${ }^{36}$ Michael Billig, Ideology and Opinions: Studies in Rhetorical Psychology (Cambridge University Press, Cambridge, 1991).

${ }^{37}$ See Glasius and Meijers, 2012, for our application of the same method to the Charles Taylor trial before the Special Court for Sierra Leone.
} 
defense used these as occasions for more extensive (in Harris' term "narrative") ${ }^{38}$ statements of their own. ${ }^{39}$ This left us with approximately 30 percent of the transcripts, which we subjected to a close reading. ${ }^{40}$ On the basis of this analysis, two master coding frames, ${ }^{41}$ one for the prosecution and one for the defense, were drawn up and continually adjusted until theoretical saturation was reached. Additionally, the entire 15,000 page set of transcripts was subjected to certain word searches that emerged from the manual coding as particularly salient. Interviews with Karadžić and press conferences by the chief prosecutor were also analysed, and visits were made to the Court in order to directly observe the "courtroom drama." 42

The ICTY's chief prosecutor, Serge Brammertz, has only appeared in court once in the Karadžić case, when the defendant had just been arrested and made his first appearance. Since then, the case has been led by two prosecutors: Alan Tieger and Hildegard UertzRetzlaff speak in court with more or less equal frequency. Their discourse can be considered as a collective effort without clear distinctions between the two speakers. Both make frequent use of Karadžić' own public and private statements during the war to make their case.

Karadžić represents himself in court, supported by his lawyer Peter Robinson. Robinson, however, plays his role mainly off-stage, and talks in court only sporadically and only on legal issues. In analyzing the discourse for the defense, we solely focus on what Karadžić has to say and ask in Court. Like the prosecution, he draws heavily on his own statements and statements made by people who played a part in the peace-negotiations to construct, as we will show, a narrative on the conflict almost linearly opposed to that of the prosecution.

\footnotetext{
${ }^{38}$ Sandra Harris, 'Fragmented Narratives and Multiple Tellers: Witness and Defendant Accounts in Trials', Discourse Studies 3, 1, at 57 (2001).

${ }^{39}$ Since there was a substantial amount of material to analyse from the 'direct speech' of the prosecution on the one hand and the defendant and his lawyer on the other hand, we did not analyse whether or to what extent both sides tried to or succeeded in making points indirectly through the questioning of witnesses.

${ }^{40}$ About one-third of this material, or $10 \%$ of the total pages, were read by both of us for intersubjective validation of the analysis and coding.

${ }^{41}$ The master frames, too long to reproduce, will be available on our personal website.

${ }^{42}$ On 20 January 2011, 21 March 2011 and 11 July 2011.
} 


\section{Discourses Concerning the War and the Crimes}

In their case before the tribunal, the prosecutors devote particular discursive attention to Karadžić' rhetorical preparation of the Bosnian Serb population for the crimes to be committed; his complete and utter control over all Bosnian Serb political and military activity during the war years; his motivations; the terror unleashed on Sarajevo; the brutality of the camps in which Muslims were held prisoner; and the paradigmatic crime of the Yugoslav wars, the Srebrenica massacre. Karadžić on the other hand gives a historic account in which Serbs are structurally under threat from other groups, emphasizes the numerical superiority and aggressive intent of the Muslim side, interprets his actions in the light of a collective Serb self-preservation effort, and attributes much of the evidence to Muslim trickery designed to deceive the international community. In the section below we demonstrate the way the discourses mirror each other by structuring the material according to Burke's five key terms in dramatism, applied to case construction in criminal trials by Bennett and Feldmann. ${ }^{43}$

\section{A. Scene: Bosnia in the Lead-Up to War}

In his opening statement, prosecutor Alan Tieger describes pre-war Bosnia in general and Sarajevo in particular, as an idyll of multi-ethnic integration:

"Before the war, Sarajevo had a population of approximately half a million inhabitants, a rich cosmopolitan mixture of Serbs, Croats, and Muslims as well as people who chose to identify themselves simply as Yugoslavs ... its people shared a genuine sense of community which transcended ethnic lines and which was reflected in their everyday lives. Citizens of different ethnicities intermingled freely. They intermarried at an unusually high rate. They visited on each other's holidays, regarded each other as simply neighbours. In

\footnotetext{
${ }^{43}$ Burke, K . A Grammar of Motives. (University of California Press, Berkeley, 1945) p. xv-xxiii; Bennett, W.L. and M.S. Feldman, Reconstruction Reality in the Courtroom (New Brunswick: Rutgers University Press, 1981) at 62-63 and 96-98. Naturally we recognize that this particular organization of the material is not inevitable, but constitutes an interpretive choice on our part.
} 
short, Sarajevo was the embodiment of a multi-ethnic Bosnia and the embodiment of its ethnic diversity. ${ }^{44}$

Radovan Karadžić is responsible for the destruction of this idyll. Against this sketch of Bosnia before the war, Karadžić paints a grimmer picture against the background of which we should see the conflict as it took place in Bosnia Herzegovina. Because the Serbian people in Bosnia have lived on the borders of Europe for centuries, they were the ones protecting Europe from Muslim invasion. For a long time, the Serbs of Bosnia had to live on under Ottoman rule. ${ }^{45}$ Serbian culture was oppressed: in "Turkish times we were a docile people, suffering and trying to preserve their culture through 500 years of unbearable conditions." 46 The peoples living in Bosnia today are all Serbs, but many were "converted to Islam against their own will.",47

During the Second World War there was a "genocide"48 against the Serbian people of Bosnia, committed mostly by fascist Croatian Ustashas. It is only because of this genocide that the Bosnian Serbs are no longer a majority in Bosnia: "they were reduced because of the genocide during World War II. Otherwise, they were always a majority population before." ${ }^{49}$ The Ustashas "according to the [Wiesenthal] centre, killed 500,000 Serbs, expelled 250,000 and the others were converted." ${ }^{, 50}$ But not only the Croats were associated with Nazi regime: the Grand Mufti of Jerusalem, "Hitler's friend," 51 was Muslim leader Izetbegović "guest of honor" during the Second World War. Their meetings "resulted to the creation of one and then another one SS Waffen and Handzar Division, composed of Bosnian Muslims." ${ }^{, 52}$ They were "the most cruel troops in Hitler's army.,"53

\footnotetext{
${ }^{44}$ Transcript page 591, lines 6-17, see also 515/12-13, 526/7-8; 526/21-22; 3094/8; 9799/15 for references to the ethnic diversity and intermingling in Bosnia in general or Sarajevo in particular. The full transcripts of the Karadžić trial are available at: http://www.icty.org/case/karadzic/4\#trans

${ }^{45}$ Transcript 810/6-8; 861/11-12, 21-22; 965/23; 3677/18-19.

${ }^{46}$ Transcript 828/19-22.

${ }^{47}$ Transcript $1774 / 16-17$.

${ }^{48}$ Transcript $881 / 1 ; 881 / 5 ; 913 / 8 ; 3200 / 12$.

${ }^{49}$ Transcript 881/5-7.

${ }^{50}$ Transcript 859/3-6.

${ }^{51}$ Transcript 882/9 ; for more remarks on the Mufti's relation with Hitler see $1577 / 19 ; 2920 / 16-17$; 3210/1819.

${ }^{52}$ Transcript 1577/24-1578/2.

${ }^{53}$ Transcript 3676/8-9.
} 
Under Tito, the borders of the constituent republics of Yugoslavia were drawn "totally arbitrarily . . . Tito said it doesn't matter." ${ }^{54}$ Izetbegović plays a central role in Karadžić's discourse on this period too. Izetbegović's manifesto the Islamic Declaration, published in 1969, is cited extensively: "there can be neither peace nor co-existence between the Islamic religion and non-Islamic social and political institutions" be superior to all others, and every effort should be made to create an environment in which everyone will be of pure Muslim blood." ${ }^{56}$ Karadžić asks a witness: "Do you agree that that is hate speech, even speech based on racism?" 57

Bosnia, on Karadžić competing narrative, was not an idyllic multi-ethnic country but a historic battleground with ever-lingering tensions between ethnic groups and with an ever-lingering danger of Serb oppression by radical Muslims. Karadžić, on his view, cannot be held responsible for the destruction of the Bosnian multi-ethnic idyll because there never was such a Bosnia.

In the prosecution's version, Karadžić made discursive preparations for ethnic cleansing with speeches in which he used various metaphors to demonstrate that Serbs could not live together with Muslims in particular, or at least not without losing their own identity: they were like "dogs and cats" or "incompatible plants." The prosecutor's version of Karadžić's speeches in the early 1990s are largely consistent with Karadžić's own account of the history of ethnic relations in court. Both Muslims and Croats were historic enemies: Muslims were "Turks" and fundamentalists seeking to overwhelm Serbs through their birthrate, whereas Croats were Ustasha, World War II fascists. ${ }^{58}$ The dissemination of these views by Karadžić is not just inferred by the prosecutors, but peppered with quotations from Karadžić speeches before and during the war. Far more extensive attention is given to

\footnotetext{
${ }^{54}$ Transcript 898/17-19.

${ }^{55}$ Transcript 892/17-20. Karadžić refers to the Islamic Declaration 35 times up till May 2011.

${ }^{56}$ Transcript $1586 / 18-20$.

${ }_{58}^{57}$ Transcript 1586/21-22.

${ }^{58}$ Transcript 546-547. See also 550/22; 558/14, 18; 565/16;1464/18-21; 1489/20-24; 1496/1-2; 1497/3-6; $1498 / 1-2 ; 2668 / 2-7 ; 2668 / 11-12$ on the characterization of Muslims and Croats and the impossibility of living together as attributed by the prosecution to Karadžić. See below for Karadžić's rhetoric on these issues during the trial.
} 
Karadžić' characterization of and relation to the Muslim population and leadership than to the Croats.

Karadžić however points not at his own activities, but at the Bosnian Muslim leadership as the aggressor and the criminal group in the Bosnian crisis. When Yugoslavia collapsed the Muslim leadership, headed still by Alija Izetbegović, saw this as an opportunity to realize their old dream of a Muslim dominated Bosnia: "100 per cent power, just like in the day of the Ottoman empire." ${ }^{59}$ We are presented by Karadžić with an enemy driven by religious extremism and lust for power, who "sought an Islamic state."60 Their example was the Iranian revolution. ${ }^{61}$ These fundamentalist Muslims identified "Serbs as the enemies"62 or at best as "guests" "63 who did not belong in Bosnia. They embarked on a holy war to gain control of Bosnia: "This is the new mentality, the mentality of Jihad." 64 The accomplishment of the Muslim goals, dominating Bosnia, in "a community which is religiously and politically so profoundly mixed," according to Karadžić can only be based "on terror or possibly foreign intervention." ${ }^{\prime 65}$ Karadžić avoids blaming all Muslims: "we don't believe that that's what the Muslim masses wanted." ${ }^{\prime 66}$ But unfortunately "that group chose to manipulate the SDA [Stranka Demokratske Akcije, the Bosniak Party] and the entire Muslim community."67

But the Muslims were not the only enemy. According to Karadžić, Izetbegović managed before the war in 1991 to make a "secret agreement" 68 with Croatian president Franco Tudjman. The Croats started using symbols and names of fascist units that participated in the genocide against the Serbs in the Second World War, like the name Ustashas, the checker-boarded flag, and insignias. This "was terrifying, both for the Serbs

\footnotetext{
59 Transcript 810/7. In his opening statement alone Karadžić refers to ' 100 per cent power' 11 times: see master frame.

${ }^{60}$ Transcript 884/8-9.

${ }^{61}$ Transcript 886/7-8.

${ }^{62}$ Transcript 886/14.

63 Transcript 811/6.

${ }^{64}$ Transcript 2278/4-6.

${ }^{65}$ Transcript 889/19-22.

${ }^{66}$ Transcript 889/15-19.

${ }^{67}$ Transcript 889/20-21.

${ }^{68}$ Transcript 14412/22-24. See also 921/8-13; 906/23-25; 942/14-21; 2745/3-5; 2745/20-21; 2913/5-7.
} 
and the Jews." 69

Moreover, Germany supported Croatian independence and scuppered peace in Bosnia by stimulating Izetbegović not to accept any agreement with the Serbs. This made the historic alliance of Muslims and Croats backed by Germans against the Serbian people of Bosnia complete. Karadžić cites the Croatian-Jewish writer Goldstein: "1941, the year that is returning."70 Karadžić points out that the Serbs "faced the same plans, the same villains, and the same victims as in World War II." "71 Serbs, with such enemies, had every reason to be afraid and take precautions: "well, if our neighbours are preparing a programme of this kind and life of this kind, of course we're going to separate from them."72

\section{B. Actor and Agency: Architect or Victim}

Prosecutor Alan Tieger sketches the "receptive audience" Karadžić had for his speeches. He even quotes from two other Bosnian Serb politicians, whose utterances appear considerably more radical than those of Karadžić: Muslims are "foul non-Christians who have befouled this soil of ours"73 who "had in mind . . . to gouge out our eyes and carve us up, hack our bodies to pieces, rape women and girls in front of their dearest, to circumcise, to destroy our religion, to crush us." ${ }^{, 74}$ Nonetheless, Karadžić is portrayed as the ultimate driver of this propagandistic discourse rather than just one of its mouthpieces. Karadžić himself is not considered as actually driven by ethnic hatred towards Muslims or Croats himself, but by a strategic vision. "This case, Your Honours," Alan Tieger tells the judges and the world, "is about that supreme commander, a man who harnessed the forces of nationalism, hatred, and fear to implement his vision of an ethnically separated Bosnia: Radovan Karadžić." 75

As in other high-profile trials of political leaders, one of the challenges for the prosecution is to prove that the suspect had individual criminal responsibility for crimes that were physically perpetrated much lower down the chain of command. Although Karadžić is

\footnotetext{
${ }^{69}$ Transcript 863/5-6.

${ }^{70}$ Transcript 863/6-7.

${ }^{71}$ Transcript 884/8-9.

72 Transcript 889/13-14.

${ }^{73}$ Transcript 548/19-20.

${ }^{74}$ Transcript 549/4-6.

75 Transcript 515/8-10.
} 
charged with a set of joint criminal enterprises (JCEs) committed in concert with others, the prosecution portrays him as the grand mastermind behind each plan-with Milosevic as a background aider and abettor and other Bosnian Serbs mainly as implementers. Based on a phrase used in an intercepted telephone conversation with Milosevic in October 1991, Karadžić is described as having undertaken a series of "calculated steps",76 to implement six "strategic objectives,"

In implementing these objectives, Karadžić' control over Bosnian Serbs is said to have been absolute. Other bodies of the Bosnian Serb polity are described in mechanical terms. The political party SDS is "a powerful machine with President Karadžić at its helm,"79 the Bosnian Serb Assembly a "valuable instrument," Ministers ... the precursor to the government, was another vehicle for implementing Karadžić's policies and calculated steps." ${ }^{81}$ Moreover, he "did not merely step into a position of power; he . . created and then he led the bodies and forces necessary to implement his objectives." 82

In his opening statement, the prosecutor stresses thirty-two times Karadžić's role as the supreme commander of the army, ${ }^{83}$ which put him in charge of Ratko Mladić. He was also president of everything: president of the party SDS, ${ }^{84}$ president of the National Security Council, ${ }^{85}$ president of the three-person presidency ${ }^{86}$ that ran the unrecognized republic for a while, and finally sole president of Republika Srpska. ${ }^{87}$ Party organs were "hierarchical and

\footnotetext{
${ }^{76}$ Transcript 533/14; 535/18.

77 Transcript 558/21, 25; 559/4, 6, 9; 562/20;563/2, 12, 14; 563/20-23; 564/3, 8; 567/7-8; 568/3-4, 7, 21-22; 569/6, 14, 19; 570/4; 573/19-20, 25; 575/2; 592/17, 19; 593/24-25; 594/2; 607/24; 608/8.

${ }^{78}$ Transcript 520/12;525/4; 529/18; 533/6, 20;534/4;538/22;539/13; 547/2, $13 ; 550 / 25 ; 555 / 12 ; 558 / 11-13$, 19,$24 ; 563 / 17,19-21 ; 565 / 20 ; 567 / 7-8$.

${ }^{79}$ Transcript 527/3.

${ }^{80}$ Transcript 534/12.

${ }^{81}$ Transcript 535/17.

${ }^{82}$ Transcript 525/19-20.

${ }^{83}$ Transcript 513/23; 514/8, 13, 22; 515/8;521/6;521/22;560/21;561/2, 6-7; 562/14; 604/3, 4-5; 607/17; $607 / 22 ; 608 / 8 ; 619 / 3 ; 627 / 18 ; 628 / 10 ; 639 / 8 ; 640 / 3 ; 648 / 2 ; 650 / 13 ; 651 / 12 ; 652 / 5 ; 652 / 6 ; 655 / 9 ; 656 / 2$; $659 / 21 ; 664 / 23 ; 665 / 23 ; 672 / 13$.

${ }^{84}$ Transcript 515/13; 520/22; 527/4; 528/11; 534/25; 536/16; 539/18; 672/13.

${ }^{85}$ Transcript 520/24; 536/18; 582/22; 604/5.

${ }^{86}$ Transcript 521/2, $11 ; 536 / 20 ; 560 / 14,19 ; 604 / 4,6 ; 627 / 19 ; 12976 / 19$.

${ }^{87}$ Transcript 521/4, 22; 535/10; 536/1; 536/7, 21; 560/17, 20; 561/1, 2, 7, 12, 16, 21; 583/4; 584/5, 7; 609/17; $639 / 11,16 ; 640 / 16 ; 654 / 21 ; 12976 / 18$.
} 
centralized" 88 , "able to reach the most remote village in two hours" ${ }^{\text {" }}$ Thus, "in either capacity, indeed in any of his capacities ... whether as president of the Presidency in charge of military affairs or as sole president, he was the de jure and de facto military leader, the supreme commander" 90 and "in those dual roles with that absolute authority, he effectively planned, directed, controlled, and oversaw his military subordinates."91 Again, Karadžić paints a different picture of the period leading up to the war. He maintains that he was not planning the war, that he was not an architect, but that he and the Bosnian Serb leadership did all it could to cooperate with, and make concessions to the Muslim leadership: "Thanks to the Serb's flexibility and numerous concessions that they made, there were several solutions that could have provided the avoidance of war and the price of war." 92 Karadžić "always advocated peace and peaceful solutions, never, ever advocating war."93 The Serbs "wanted to live with Muslims, but they didn’t want to live under Muslims.",94

Time after time the Serbs were, in Karadžić version of what happened, betrayed because "they [the Muslims] falsely negotiated, and they left traces that they engaged in false negotiation, whereas bona fides they were preparing for war." 95 He rhetorically asks witness for the prosecution Aernout van Lynden: "Who avoided peace conferences and peaceful solutions? The Serbs or the Muslims? It's a simple answer." 96

According to Karadžić, the Muslims had been preparing for war for months, by transforming the police into a criminal partisan army, by organizing religious paramilitary groupings (called "Mosque Doves" and even a "Mujahedin" division) led by clergymen, ${ }^{97}$ by acquiring arms and especially the call for "general mobilization." 98 By scuppering peace and by refusing to compromise their goal of " $100 \%$ in $100 \%$ of Bosnia" the Muslims

\footnotetext{
${ }^{88}$ Transcript 527/17; 527/23; 528/7, 9; 606/16;4216/6; 4218/7; 12935/9; 12963/1-3; 12977/19; 14212/17; $14214 / 25 ; 12935 / 9 ; 12936 / 14-12937 / 23 ; 12938 / 2-3 ; 12938 / 16-17 ; 12938 / 25 ; 12939 / 3 ; 12942 / 20$.

${ }^{89}$ Transcript 527/14-15.

90 Transcript 560/20-21.

${ }^{91}$ Transcript 607/17-18.

92 Transcript 827/4-7. See also 822/23; 837/14; 911/9-10; 932/19-20; 958/15-16; 2865/10-11.

93 Transcript $14442 / 22$.

${ }^{94}$ Transcript 848/23-24.

${ }^{95}$ Transcript 969/5-7. See also: 848/23-849/1; 883/18-20; 884/3-5; 968/9-11; 2688/15-21; 2700/5-11.

${ }^{96}$ Transcript 2612/16-18.

${ }^{97}$ Transcript 1332/7.

${ }^{98}$ Transcript 3985/21-22.
} 
provoked war because that was the only options "Serbs could not accept." This "was the main cause of the war." 99

As a result, the Muslim forces were more dangerous and stronger then the Serbs. The Serbs where "dealing with a raging bull, but the OTP [Office of the Prosecutor] claim that they were dealing with lambs and causing lambs irreparable harm." disproportion in manpower"101: the Serbs where "outnumbered"102 by the Muslim army which was "three times stronger." 103 The Muslim army was well armed and well prepared, because they inherited arms from the Yugoslav National Army (JNA) ${ }^{104}$ and because everybody had weapons at home, due to Tito's doctrine of the "armed people."105 Moreover, "they received weapons from Iran (with the knowledge of the United States) continuously through Croatian territory." 106 The accusation of backing from Iran is especially significant since Karadžić alleges that Izetbegović wanted to model Bosnia on theocratic Iran and because Iran, as part of the 'axis of evil', has often been accused of supporting Islamist organizations abroad.

Finally, the outbreak of war in Yugoslavia, and the brutality of it, had long been considered inevitable by western observers: "even while Joseph Broz Tito was still alive, had they foreseen the outbreak of war and the brutality of war. . . . If you're going to have war in the Balkans ... you're going to have brother killing brother. How then can the Prosecution place the responsibilities for the outbreak of a civil war which the Western governments and the western services envisaged in this almost clairvoyant way, far before they had ever heard of Karadžić and the SDS, how can they link it to this accused here, and burden him and accuse him of being responsible for that?"107

\footnotetext{
${ }^{99}$ Transcript $7325 / 22$.

100 Transcript 870/24/25.

101 Transcript 2466/19-22.

102 Transcript 6880/7.

103 Transcript $870 / 16$.

104 Transcript $2740 / 10 ; 8350 / 12$. Karadžić also says that the JNA is the 'Mother of all armies' : 2739/19-20 ; $2740 / 12 ; 2973 / 6$.

105 Transcript 932/3;936/17; 1056/14;2456/11;2741/21;2849/4;36208; 3783/12;3796/9, 24; $3797 / 5,8,10 ; 3896 / 6 ; 8455 / 15 ; 12019 / 8$.

${ }_{106}$ Transcript 2744/18-20. Support from Iran is also mentioned at $1677 / 11 ; 2739 / 17 ; 3670 / 25 ; 5785 / 17$.

107 Transcript 834/5-17.
} 
Karadžić portrays himself not so much a political leader but as a Christlike figure for the Serbian people: "They said Karadžić was the ultimate leader. If they knew the Serbian people properly, they would have said that Karadžić was the ultimate servant of his people, and this is what you can find in-in the Gospels." 108

\section{Purpose: Living Space or Self-Protection}

As suggested above, and somewhat in contradiction perhaps to his representation in the international media, Karadžić is not described by the prosecution as having been driven by ethnic hatred per se. His motivation is to provide "living space" 109 for the Serbian people in Bosnia by "carving out"110 and "conquering""111 "vast"112 and "huge"113 territories. Directed by Karadžić, officials of the party, the police, the remnant of the Yugoslav national army and paramilitary groups are all involved in "liberating the space" 114 for the Serb people. Liberation entailed making the territory "pure" 115 through "ethnic cleansing,", the signature phrase of the Bosnian war.

Karadžić' own account paints him as a thorough cosmopolitan: "all my business contacts in Sarajevo were mostly with Muslims? I don't want to enumerate them all, not to waste time. The professor who taught me clinical psychiatry was a Muslim, and I chose him. My internal medicine professor was a Croat, Ivan. My dentist, according to my own choice, is Faruk, a Muslim. My lawyers, once again due to my personal choice, are Ekrem and-I know the surname but I'll remember his name too. He was also a Muslim, and I think he originated from Kosovo. That my hairdresser is a Muslim, or barber, and that everything I did in Sarajevo was mostly linked to the Muslims." "117

\footnotetext{
108 Transcript 853/21-23;

${ }^{109}$ A term reminiscent of Nazi ideology of course, and actually used by Karadžić. Transcript 525/5; 545/24; 568/10, 25; 4483/19; 4485/7; 13338/16.

110 Transcript 514/9.

111 Transcript 515/17, 23; 516/25; 517/6; 518/20; 520/18;549/25; 550/15; 552/6; 560/1; 585/2; 587/12, 16, 19, $22 ; 590 / 10,21 ; 640 / 8 ; 662 / 4 ; 3600 / 21 ; 7238 / 8,10$.

${ }^{112}$ Transcript 514/11;518/11;546/5; 590/10.

113 Transcript 544/24; 545/12-13.

114 Transcript 544/9-10, $12 ; 544 / 21-22 ; 553 / 3 ; 556 / 18 ; 575 / 5$.

115 Transcript 549/23; 550/10; 550/20; 571/17; 572/5; 572/13; 573/3; 581/25-582/1; 588/2; 2419/4-7; 2666/812.

${ }^{116}$ The term is used by the prosecution at least 65 times: see masterframe.

117 Transcript 3282/12-22. His good relations with Muslims are also emphasized in 1608/1-2; 2924/10-15;
} 
Karadžić further counters the "living space" sketch of his motivation for the war by, again, placing all agency with his enemies in the conflict. According to Karadžić, the moves of the Muslim leadership forced all the moves of the Serb leadership in Bosnia: "Serb behaviour is a response. It's a reaction. It is impermissible, it is impossible to say that that is intention rather than reaction. The SDA decides what the Serbs are going to do." ${ }^{118}$ First, there was the establishment of political parties based on ethnicity. ${ }^{119}$ Then, the Muslims declared independence without the support of the Serbian minority. As a response, the Serbs declared independence to protect themselves against radical Islamic rule. The only thing the Republika Srpska set out to do was to "protect the Serbian people from their own state, from the police, from the state-sponsored terror of their own country." 120

Sarajevo was not a peaceful city but "a fortress and fulcrum, a military stronghold"121 that was well armed and full of legitimate targets. ${ }^{122}$ Srebrenica was attacked because, as Karadžić emphasizes on several occasions it was a "military stronghold." "123 The Serbs could not wait in a "deep state of anaesthesia ... to be butchered like the Serbs before us." $" 124$

\section{Act: Terror and Lies}

In its indictment, the prosecution constructs a complex web of Karadžić' crimes and their purposes: he is accused of having taken part in four joint criminal enterprises, the first of which over-arches the other three, which together constitute two counts of genocide, five counts of crimes against humanity and four counts or war crimes, based on factual incidents summarized and categorized in seven "schedules." Even after the judges order a substantial

\footnotetext{
${ }^{118}$ Transcript 941/14-17. For other, similar, examples see: 813/8-9; 870/2-3; 881/12-13; 941/15; 946/17-20.

${ }^{119}$ Transcript 869/14-18.

${ }^{120}$ Transcript 933/11-13.

${ }^{121}$ Transcript 1906/ 22-24.

${ }^{122}$ For some examples see Transcript 954/19-25; 955/3; 955/5-8; 957/18-958/4; 1930/4-7; 2351/2-10; 2470/1; $2472 / 7-8$; 2472/13-14; 2472/7-8; 2473/6-8; 2474/1; 2496/1-6; 2510/4-2511/3; 2517/13-16; 2589/9-17; 2727/621; 2911/20-22; 1906/22-24; 1916/12-18; 1921/22-24; 1922/3-4; 1923/3-6; 1925/7-12; 1929/18-19; 1967/5-6; 1968/17-22; 2075/15-17; 2277/14018; 2338/11-2339/18; 2454/12-22; 2455/8-16; 2551/8-12; 2554/2-8; 2599/8-13.

${ }_{123}$ Transcript 981/23; 1419/1-2; 2220/16; 7403/4-5; 10277/13; 11625/10.

${ }^{124}$ Transcript 866/7-8.
} 
reduction in the number of these incidents put forward in evidence, the case is, according to the assessment of both parties, "vast." However, the bulk of the accusations can in fact be considered to belong to one of four categories: the shelling and sniping of Sarajevo, the forced expulsion and detention of Muslims and Croats from various parts of Bosnia, the Srebrenica massacre and the hostage-taking of United Nations personnel. The last of these four points had been given little attention by the prosecutors during the period under investigation, and will not be discussed here.

The characterization of the Sarajevo campaign by the prosecution is particularly intriguing, as it focuses on a concept that has been centre-stage in the international political discourse of the last decade, but has not traditionally belonged to the vocabulary of humanitarian or criminal law: terror ${ }^{125}$. According to count 9 of the indictment, Karadžić' men committed "crimes of terror," "the primary purpose of which was to spread terror among the civilian population" by means of shelling and sniping. While also covering some actual incidents of sniping and shelling, the prosecutors devote much attention to describing the "atmosphere of terror" 126 that engulfed the city: [T] error was the only constant in the otherwise uncertain daily life of these besieged Sarajevans." 127 "Simple daily acts like crossing the street terrified people."128 "For 44 months, the civilian population lived under a pervasive sense of terror; exactly what was intended."129 "This terror attack, Your Honours, virtually killed a living city."130

Although unlawful killings are also separately charged, making the people of Sarajevo afraid for their lives is constituted as a war crime in itself. Even Karadžić' ally Milosevic is said to have "described the earliest bombardments as 'bloody criminal.",131 However, instilling fear appears to be just an intermediate purpose, with as ultimate aims: "to secure concessions from the Bosnian government and the international community, the

\footnotetext{
${ }^{125}$ See Glasius, Marlies (forthcoming). 'Terror, terrorizing, terrorism: Instilling fear as a crime in the case of Radovan Karadzic and Charles Taylor', Slavic Review (2014) for a more extensive discussion.

126 Transcript 602/13/14.

127 Transcript 599/12-13.

128 Transcript 599/18.

129 Transcript 597/17-18.

130 Transcript 601/25-602/1. The words 'terror', 'terrorize', 'terrorization' are used at least 61 times by the prosecutors: see master frame.

${ }^{131}$ Transcript 615/5-6.
} 
interest in exacting revenge, the interest in securing concessions in negotiations to cement gains and to obtain a resolution consistent with the objectives of the Bosnian Serbs."132 Perhaps surprisingly, the allegation of terror is exclusively reserved for the siege of Sarajevo. The forced expulsion, internment in camps, and other crimes against the non-Serb population are not claimed to have been aimed at terrorizing civilians.

The use of terror is also imputed by Karadžić to the Muslims, but with a twist: the Muslims did not only sow terror, they were also terrorists. The Muslim leadership tried to realize "the implementation of [their] ideology ... with both terror and foreign intervention." 133 Serbs where "terrorized"134 by Muslim forces who undertook "terrorist . . . activities." 135 The Muslims were "organising and preparing terrorist organisations against prominent Serbs."136

At the beginning of the war "there was terror exercised by the Muslims against the Serbs. There were rapes of young girls on an ethnic basis, and there were killings."137 Later it was "terror in Sarajevo . . . it was terrible to be a Serb that night in Sarajevo."138 Also in Srebrenica "there was terrible terror exercised by the Muslims of the area." "139 Unlike the Muslims: "we [Serbs] do not have a tradition of terrorism, and we are against killing.,"140

The prosecutors bring forward a host of incidents involving beatings, sexual assaults and other abuse, and instances of killings that happened in the context of the camps in which especially male, but sometimes also female Muslims and Croats were held. Food, water and sanitary facilities were generally insufficient or lacking. The prosecutors acknowledge that conditions varied between camps, but they were generally squalid, ${ }^{141}$ degrading, ${ }^{142}$ and

\footnotetext{
132 Transcript 198/16-19.

133 Transcript 889/3-4.

134 Transcript 5449/1; 5451/1; Other references to terror/terrorism by Muslims can be found at: 928/17; 958/25; 965/8; 972/4; 973/19;1932/13; 1968/20;4354/19;4804/10;4926/13; 7970/7; 11425/7; 11692/1; 11944/20; $11945 / 12 ; 11983 / 13 ; 12101 / 16 ; 15154 / 24 ; 15644 / 18$.

135 Transcript 11692/1.

136 Transcript 11945/12; 11983/13.

137 Transcript 972/4-7.

${ }^{138}$ Transcript 928/17.

${ }^{139}$ Transcript 978/14.

${ }^{140}$ Transcript 2860/17-18.

${ }^{141}$ Transcript 515/19.
} 
wretched. ${ }^{143}$ In short, they dehumanized their inmates: Non-Serbs [were] "sent to camps where detainees lived like animals and were abused, raped, and killed."144 These camps "were degrading and typically brutal places situated in such locations as old mines, abandoned factories, old concrete buildings, and the like. In the best of circumstances, detainees existed in dehumanising conditions." $" 145$

However, the purpose of these "concentration camps" ultimate solution ... would be to exchange the prisoners, that is, send them to Muslim-held areas in exchange for Serbs held by Muslims. And in that way, the separation process which had begun with the forcible removal of Bosnian Muslims and Croats with their wholesale round-up could be completed as they were transported out of Republika Srpska." ${ }^{147}$ Hence, the inhumanity of the camps too was not a purpose in itself, but a means to cleanse territories for the Serbs.

The prosecutors' description of Karadžić' responsibility for the massacres at Srebrenica relies on detailed, factual descriptions of killing operations at various sites, and construction of Karadžić' knowledge of these based on telephone intercepts. They do not require hyperbolic statements to describe an event that already has the status of “one of humanity's dark chapters" "148. "Srebrenica was once simply the name of a small town and municipality in Eastern Bosnia . . . In July 1995, however, Srebrenica achieved worldwide infamy."149 Instead, more indignation is reserved for Karadžić' partial denial of the massacre and lack of regret $^{150}$ than for the act itself. Karadžić is not one of those

who out of nationalist fervour may stubbornly or naively claim that Srebrenica never happened . . .when that man [Karadžić] denies what happened, it is because he knows that the truth condemns him. But

\footnotetext{
${ }^{142}$ Transcript 576/25.

143 Transcript 586/9.

144 Transcript 524/1-2.

145 Transcript $576 / 25$ to $577 / 2-3$.

146 Transcript 4562/25; 4563/21; 4588/5.

147 Transcript 581/7-12.

148 Transcript 623/14-15.

${ }^{149}$ Transcript 624/4-5, 9.

${ }^{150}$ Transcript 624/1; 665/15.
} 
the living victims, the survivors, the women, elderly, those who were children in Potocari in July 1995, for them there is no question of what happened, only the lasting pain of loss. . . . Their ongoing tragedy, Your Honours, is part of the lasting legacy of the accused's crime and part of the overwhelming evidence that belies his efforts at denial. $^{151}$

Thus, Karadžić is emphatically separated from other nationalistic Serbs: his motives for denial are different, instrumental, and altogether more blameworthy.

Karadžić, while not specifically denying that deaths occurred in Srebrenica, accuses the SDA of using "tricks"152 to provoke foreign intervention: they did terrible things to "their own people" 153 and then blamed Serbs. They could do this because their actions were "deeply founded on a belief, on a philosophy, political philosophy, that the people should suffer a great deal in order to return to Islam."154 The examples that Karadžić gives range from Muslims firing from hospitals in order to provoke Serb retaliatory fire on the hospital, the Bosniak government storing humanitarian supplies to create scarcity and blame Serbs for not letting through supplies, and the shutting down of utilities to accuse Serbian forces of cutting them off. They also "fired at their own people"155 and "staged various dramatic incidents around the city" 156 of Sarajevo. They also planted false evidence against the Serbs. Karadžić claims that this happened twice at the central market in Sarajevo (Markale) and in Srebrenica. In Markale "the whole scene was rigged, with dead bodies — already dead bodies planted there." 157 The same effect was reached by accusing the Serbs of killing civilians, whilst "for the entire first year of the war, there were no uniforms, and if the person was

\footnotetext{
151 Transcript $665 / 21$ to $666 / 9$.

152 Transcript Karadžić refers to Muslims using a 'trick' or 'tricks' explicitly 64 times: see master frame.

${ }^{153}$ Karadžić refers to what the Muslims did to 'their own people' literally more than 30 times. See Transcript $2872 / 5 ; 3041 / 16 ; 2042 / 25 ; 4229 / 13 ; 4289 / 3,21 ; 4318 / 7 ; 5549 / 16 ; 5889 / 7 ; 6815 / 10,16 ; 6816 / 18 ; 7305 / 24$; $7326 / 22 ; 7328 / 19 ; 7330 / 10 ; 7359 / 21 ; 8051 / 12 ; 8054 / 6 ; 8059 / 24 ; 8457 / 9 ; 10164 / 16 ; 10165 / 4 ; 10196 / 9$; $10202 / 4 ; 10515 / 14 ; 11527 / 18 ; 11556 / 1 ; 13119 / 7 ; 13501 / 23$.

154 Transcript 1640/1-3.

155 Transcript 3041/16; 4229/13.

${ }^{156}$ Karadžić refers to 'staged' incidents at Transcript 823/9-12; 967/3; 1687/14; 2571/18; 4229/18; 4318/66-7; 5580/7-10; 6207/20-22; 9095/7; 9099/10; 9580/16; 9920/12; 10011/24; 10623/9; 11517/6.

157 Transcript 9921/10.
} 
killed wearing civilian clothing did not mean that it - he was a civilian."

\section{Discourses on the Trial and the Tribunal}

Despite the unremittingly contentious status of the tribunal in the Balkans region, and the particularly high profile nature of the Karadžić case, the prosecution does not explicitly explain what the Karadžić case is for. The unspoken assumption would appear to be that the purpose is to establish the facts about the guilt or innocence of Radovan Karadžić with regard to the crimes of which he is accused, and nothing more. The prosecution throughout assumes the legitimacy of the tribunal, and of this particular case. It never engages in defending this - either in court or in public. In sharp contrast to how well the details of the case are mirrored in both versions of the conflict, there is a discontinuity between the extensive reflections by Karadžić on the nature of the tribunal and the case, and the prosecution's relative silence in this respect. Having noted the silence of the prosecution, we now go on to present and analyze Karadžić' discourse on the trial's legitimacy.

Initially, Karadžić challenged the legitimacy of the ICTY itself, expressing that he is "deeply convinced that this court is representing itself falsely as a court of the international community, whereas it is in fact a court of NATO whose aim is to liquidate me."159 $\mathrm{He}$ points out that "I will defend myself before this institution as I would defend myself before any natural catastrophe, to which I also deny the right to attack me." ${ }^{160}$ However, he quickly stops questioning the legitimacy of the entire court - even before the opening speeches are delivered. He does go on to question the tribunal's jurisdiction in his particular case in the light of an alleged agreement between him and Richard Holbrook, to the effect that Karadžić would disappear from public life and would not be prosecuted for his role in the conflict. ${ }^{161}$

He also repeatedly complains about the inequality of arms between himself and the prosecution. His requests and demands for more time and more support are generally granted by the judges or by the appeals chamber, which makes the complaint that the trial is

\footnotetext{
${ }^{158}$ Transcript 971/9-11.

159 Transcript 31/17-19.

${ }^{160}$ Transcript 20/16-19.

${ }^{161}$ Karadžić points to the Holbrook agreement 50 times in the transcript (see master frame), and mentions it in all interviews he gives.
} 
unfair on procedural grounds harder to sustain.

In the early stages of the trial, the prosecution initially displays considerable irritation with Karadžić' delaying tactics, which consisted of first insisting on representing himself, and then refusing to attend court hearings because he did not feel fully prepared: "The accused, while all the way opposing today's start of trial, has used all the legal remedies he had available ... In other words, the trial can only start if the accused says it should. . . Preventing the commencement of trial in this manner would substantially and persistently obstruct the proper and expeditious conduct of this trial." 162

After Karadžić has come around and taken up his role as his own defence lawyer, the prosecution occasionally berates Karadžić for the manner in which he approaches witnesses, ${ }^{163}$ but more often leaves this to the judges. The occasions on which either the judges or the prosecution intervene in Karadžić' line of questioning are more often to do with time-wasting than with inappropriate behavior, and diminish over time. Instead, there is more of a sense of the defense, the prosecution and the judges being engaged in the common enterprise of getting through the trial. By Spring 2010, the two parties engage in out-of-court talks to agree a full list of documents, ${ }^{164}$ Karadzic gets thanked by a prosecutor for his help in locating the appropriate passage in a document, ${ }^{165}$ and he apologizes profusely for failing to give notice to the prosecution about the use of a particular document. ${ }^{166}$

After the initial squirmishes concerning jurisdiction and equality of arms, Karadžić points his arrows no longer at the judges, but exclusively at the prosecutors. They are "onesided" and have taken the Muslim side in the conflict, just as NATO did during the war. In this way, they are "trying to turn this Tribunal into a disciplinary commission of NATO."167 The prosecution portrays Karadžić as a "barbarian"" 168 and "as a monster . . . due to the fact

\footnotetext{
162 Transcript 504/17-19; 505/4-5; 506/19-20.

${ }^{163}$ Although it mostly waits for the Bench to intervene. Some examples of the prosecution labeling Karadžić' manners inappropriate are at Transcript 10255/24; 11141/5;11517/10;13011/3.

164 Transcript 4256/10-13.

165 Transcript 2101/9-10.

166 Transcript 5082/18-19.

${ }^{167}$ Transcript 813/17-19.

168 Transcript 885/19-20.
} 
that they don't have any evidence, and it's going to be easier for them to prove their case if they portray the accused as a monster rather than if they portray him as a real live person."169 They try to "to link up this accused person and the chaos and tragedy of civil war."170

The prosecution represents the continuation of the conflict, not against Karadžić personally, but against the Serbs of Bosnia: "what I'm being accused of by the Prosecution in their false indictment I would like to turn round and create into a genuine indictment, where everything stays the same but the actors change. Instead of the Serb leaders, the Croatian and Muslim leaders would stand accused. . . . And let's see what that would look like. Genuine indictment." ${ }^{, 171}$ About Muslim and Croat leaders, he asks "why aren't these perpetrators of enormous major crimes, with blood to their shoulders, not being tried here?"172

The prosecution criminalizes the legitimate self-defense of the Serbian people against their aggressor: "Everything the Serbs did as part of their own legitimate defense, all of that is being treated as a crime." "173 They have "good men" and "wonderful men" convicted "as if they were attacking an innocent population, not an army that was three times stronger than their own and that was committing such bestial acts." ${ }^{174}$ The prosecution uses the Muslim "war tricks" and thus becomes a "participant in the war" trying "to draw this Chamber and this Tribunal into a war that seems to be ongoing in that way"175: "They say that all is fair in love and war. I don't think that all is fair either in love or in war, but it is certain that in war these kind of things happen, but is this permissible in a courtroom, in a court of law? How does the Prosecution dare to proffer this to you as if it were the truth?",176

Karadžić directly addresses some of the functions expressivism attribute to international criminal law, such as the truth, faith in the rule of law, and even reconciliation.

\footnotetext{
169 Transcript 871/9-11.

${ }^{170}$ Transcript 814/18-19.

${ }^{171}$ Transcript 860/4-9. See also 866/10-18.

172 Transcript 813/3-5.

${ }^{173}$ Transcript 815/14-15.

${ }^{174}$ Transcript 870/11-17.

${ }^{175}$ Transcript 841/1-4.

176 Transcript 840/1-4.
} 
In his opening statement, he says that "it is with great enthusiasm that I am preparing for these proceedings." ${ }^{\prime 77} \mathrm{He}$ has been "acting in good faith in order to create a process, a trial that is going to be important for us, the peoples back there, and also for international justice and international law." "178

Karadžić is motivated "first of all, to determine the truth, the truth about our conflict, to determine the truth as I say, and then to defend myself in the second place. I'm not defending myself in actual fact. What I am defending are the people over there who suffered."179 The trial can be a "vehicle for the truth." 180 This is also the reason why Karadžić emphasizes so vigorously during his first weeks in Court and later in motions the importance that everything that happens in Court happens in public and why he attaches great importance to communication with the press. ${ }^{181}$

Moreover, "if I can have a fair trial and bring out the truth, it will be a step towards reconciliation." "182 The "lies" and the "false indictment" are a threat to peace and reconciliation: "how can one hope for reconciliation between the Serbs and Muslims if the Muslims are to believe that the Serbs did this to them?" 183 The truth about Srebrenica is particularly important in this respect: "We have to see what this is going to do to the future and what kind of seed of future hatred and suffering has been sown in this way for our children and grandchildren, . . . saying that Serbs did something that they never did, whoever does that ensures the continuation of further conflict and slaughter." 184 According to Karadžić, his trial is the "last ever opportunity" Srebrenica. In this respect, Karadžić depicts himself as being once again on the front line of

${ }^{177}$ Transcript 990/23-991/1.

${ }^{178}$ Transcript 119/11-15.

${ }^{179}$ In the initial appearance and the defence opening statement alone Karadžić emphasizes the importance of the truth 52 times: see masterframe.

180 Denis Dzidic, Interview with Karadžić, Balkan Insight, 20 December 2010. http://www.balkaninsight.com/en/article/interview-radovan-karadzic-vehicle-for-establishment-of-truth (visited 13-2-2012).

${ }^{181}$ Karadžić requests for open communication with the press: IT-95-5/18-PT, 01 May 2009, 'Motion for equality of Arms in contact with news media'. For Karadžić arguments with regard to publicity see especially Status Conference, 24 May 2009.

182 Transcript 840/19-21.

183 Transcript 840/20-24.

${ }^{184}$ Denis Dzidic, Ibidem.

${ }^{185}$ Transcript 352/15. 
Bosnia's future: "this trial is my shift on the front.",186

\section{Discourses and Expressivist Effects}

Legal expressivism as applied to international criminal trials provides a fruitful way of theorizing the potential socio-political effects of such trials, because it actually gives an account of the mechanism (messaging; play-staging) through which such effects can be reached. But in order to work not just as normative but also as an empirical theory, it requires further development. We have attempted to further the theory by pushing the theatrical metaphor. In this article we have focused on the actors, and particularly on the neglected part of the defendant. What does comparing these two narratives tell us about the expressivist potential of the trial against Radovan Karadžić in particular and of international criminal courts in general? As we have said in the introduction, expressivists suggest several different ways in which messages expressed in court can affect society: truth-telling; individualizing guilt; inflicting shame and stigma; norm-dissemination and finally, reconciliation.

\section{A. Truth Telling}

With regard to truth telling and creating a historical narrative, the problems faced are quite obvious from the discourse. In terms of the theatrical metaphor: classic Hollywood villains often reveal their evil plans to the captured hero-and to the public-before they are arrested or killed, making the truth (and the moral of the story) very clear. However, no such moment is to be expected in court, where not one, but two elaborate, detailed and internally coherent (whether both stories are coherent with the facts is another question) historical narratives are presented. Karadžić is telling a story of himself as the defender of the Serbs as a historical victim, whereas the Prosecution tells a story about how Karadžić bears the primary responsibility for the ethnic crimes in Bosnia. At the end of the trial, judges will come with the version of the story they consider true beyond reasonable doubt - most likely closer to the story of the prosecution than to Karadžić — but we cannot expect one strike of the hammer to undo literally years of well publicized trial discourses.

\footnotetext{
${ }^{186}$ Interview with Radovan Karadžić: The other side of the Bosnian Story, 'Politics First': May 2011.
} 
What matters most for expressivist messages to have the desired effect, is which narrative catches on with relevant audiences, not which one is considered true beyond reasonable doubt by the Bench. It is not unlikely that the different narratives presented in court will catch on with different audiences. Although Karadžić never explicitly addresses the Serbian people while on trial, his narrative will certainly resonate better in the Republika Srpska and Serbia. On the other side, the case made by the prosecution, in which Bosniaks figure mostly as victims of Karadžić crimes, will resonate with this group much better.

It seems unlikely that the court will be able to convince all concerned to support one official version of what happened during the war and proclaim the victory of one narrative over all others. Nonetheless there may be more modest ways in which the court might have an impact on truth telling. Fifteen years of ICTY may have contributed to narrowing down the range of plausible interpretations of the conflict. Due to the massive amounts of evidence presented in court over and over again - certain events and atrocities become close to undeniable. ${ }^{187}$ To paraphrase Orentlicher, the trials before the ICTY are "shrinking the space for denial." ${ }^{\prime 188}$ For example, it would be very difficult for anybody to deny that people were killed at Srebrenica. Indeed, we do not see Karadžić denying it, resorting instead to blurring the fighter/civilian distinction and turning around the accusation.

\section{B. Individualizing Guilt}

The prosecution takes a clear position: the person on trial is Radovan Karadžić and nobody else. The trial is about establishing his role in the conflict. It presents a powerful case that Karadžić, if not the sole responsible, is at least among those most responsible for the crimes that took place in Bosnia. The ICTY lists this as one of its achievements (perhaps more properly understood as one of its aims):

By trying individuals on the basis of their personal responsibility, the ICTY individualises guilt. Leaders and other individuals can no longer hide behind the "nation" or any other group. They have to take

\footnotetext{
187 Although never completely undeniable, given that fact that there are still people who do not believe the Holocaust happened.

${ }^{188}$ Diane Orentlicher, Shrinking the Space for Denial (Open Society Institute, New York, 2008).
} 
responsibility and answer for their own actions. Accordingly, communities are shielded from being labelled as collectively responsible for others" suffering. This can greatly contribute to preventing mutual hatred and promoting the reconciliation process within the war-torn societies of the former Yugoslavia. ${ }^{189}$

This is a point pressed by the prosecution, and this seems to be the only subject on which it appears to be consciously engaged in expressivist messaging. By emphasizing that "this case is about that supreme commander." ${ }^{190}$ before listing his crimes, and by singling Karadžić out as one of the few who can only deny Srebrenica "because he knows that the truth condemns him"191 the Prosecution very clearly sets him apart from other Serbs.

Karadžić, however, challenges the fact that the trial is about him on several occasions. The trial, on his view, is an attack on the legitimate battle of the Serbs. He does not discuss his personal role and history very elaborately, but focuses on the history and the role of "his people." This is consistent with how he presents himself in court: ascribing little agency to himself and presenting all his decisions as forced by necessity to protect his people.

\section{Stigmatization}

Another mechanism is stigmatization or the infliction of shame: making a war-criminal-forall out of a war-hero-for-some. Karadžić is the "man who harnessed the forces of nationalism, hatred, and fear to implement his vision of an ethnically separated Bosnia."192 Karadžić presents himself as a martyr for his people, hoping to find the truth and working hard for reconciliation in Bosnia-Herzegovina. Moreover, because Karadžić is doing his own defense, the interaction between the prosecution and Karadžić becomes lawyerlike. Seen from the public gallery, Karadžić - who is supposed to be stigmatized as a warcriminal-turns into a lawyer. In court he is mostly polite and obviously an intelligent

\footnotetext{
${ }^{189}$ ICTY Outreach, The Tribunals Accomplishments in Justice and Law, in Justice in Transition, no. 3 (2006).

190 Transcript 515/8-10.

191 Transcript 666/9.

192 Transcript 515/8-10.
} 
human being incomparable to the Nazi leadership at Nuremberg who inculpated themselves by their spine-shivering statements in court. ${ }^{193}$

The prosecution is not the only party who can use the stage offered by the ICTY to stigmatize defendants, but defendants are offered the same chances: Karadžić denounces the Bosnian leadership as fundamentalist radicals, the prosecution as a party to the conflict, siding with the Muslims, and initially even portrays the tribunal itself as a disciplinary court for NATO. The judges give Karadžić considerable leeway in arguing against the court and the prosecution. As we have argued elsewhere the judges find themselves in a Catch-22 situation. ${ }^{194}$ When they give the defendant considerable space, he may successfully attack the legitimacy of the trial. If they do not offer him that space, they risk giving the appearance that the defendant is not receiving a fair trial—which also undermines the legitimacy of the court. A case in point of how far the appeals bench has gone to prevent any doubt about the rights of the accused, is Karadžić' successful request for the removal of judge Alphons Orie, accused by Karadžić of being biased by the Appeals Chamber. ${ }^{195}$ Removing him might send the message that Karadžić was right to complain to at least a certain extent, whereas leaving him on the bench could also have undermined the perceived impartiality of the court.

\section{Norm-Dissemination}

This supposed effect of international criminal courts is perhaps best seen as resulting from the combination of the of the other expressivist effects. The trial, by (1) getting at the truth and (2) stigmatizing and punishing those who committed crimes through (3) a fair trial sends some clear moral signals. It sends the message that crimes of this nature cannot and will not go unpunished, nor are they to be resolved through revenge. In this way the trial presents an alternative modus of conflict resolution. However, for this expressivist potential to be realized, the different elements of the message have to be unambiguously broadcast. As we

193 See in particular Rudolph Hess' statements: Nuremberg Proceedings, Day 216 (1946) http://avalon.law.yale.edu/imt/08-31-46.asp (visited 13-2-2012).

\footnotetext{
${ }^{194}$ Glasius \& Meijers, supra note 9

195 Pros. vs. Karadžić, IT-95-5/18-I, Decision on Disqualification of Judges (21-08-2008).
} 
have discussed under other headings, this is clearly not the case when all three elements are rhetorically opposed by the defendant.

\section{E. Reconciliation}

Perhaps the most ambitious claim made by expressivism is that trials can offer reconciliation to war-torn societies, ending tension and conflict. The first step towards reconciliation is that the different parties agree on a certain version of the conflict and stop blaming each other. Interestingly enough, Karadžić makes this point in the trial, hoping that Bosnian Muslims will stop blaming Serbs for "non-existent" crimes-which demonstrates precisely that having a trial does not necessarily lead to a common understanding of the conflict. If the defendant succeeds (at least to a certain extent) in strengthening the convictions of (a substantial part of) his own faction that they are being convicted, that they were the victim of the conflict, that the court is biased against them, reconciliation cannot be expected. In a polarized society, if the version of the conflict presented by the prosecution is accepted by one group but the other group or groups buy into another version of the conflict and the court, and feel that they have been delegitimized, stigmatized, and wrongfully punished, tensions might rise rather than drop.

However, there is a more modest way in which a trial could contribute to reconciliation, strongly connected to norm-dissemination: by considering the legal spectacle as a public lesson in conflict resolution. Karadžić is forced by the nature of criminal proceedings to tone down and deal with arguments in a certain way. Although Karadžić at first tries to attack the court itself, in the end he is forced to meet the charges in a reasonable, argued way - using legally permissible arguments and evidence. Histrionic diatribes are curtailed, physical violence is unthinkable in the courtroom context. By conducting his own defence, Karadžić actually contributes to the impression that this is a civil, deliberative debate about the past, because he helps us forget that his presence in court is involuntary, and ultimately based on force.

\section{Conclusion: The Theatre of Justice?}

A. The Actors

Expressivism sees courts as theatrical spectacles, but it has yet to develop a better theory on 
the role of the actors, the audience and the stage in this theatre. The actors here fundamentally disagree on what story, what moral, they wan to convey to the public. Defendants are not always content with the part implicitly assigned to them by the expressivists, bowing their head in shame and silently awaiting judgment for several years. Instead, the Karadžić case shows how they may disturb and contest the presentation of what happened during the war, the individualization of guilt and the legitimacy of the proceedings itself.

Moreover, Karadžić' complaints about the legitimacy of the court and the anti-Serb nature of the case largely go unchallenged by the prosecution-both inside the courtroom and outside of it. The prosecution only plays the antagonistic game on one of the levels Karadžić' challenges them: the matter of his legal responsibility for the crimes. A defendant like Karadžić on the other hand paints on a larger canvass: he is concerned with the history of "his people" and his own place in it. In order for courts to realize their expressivist potential, a more public relations oriented approach by prosecutors as well as judges might be desirable; defending their existence to the public outside the courtroom, and making clear and arguing for what they wish the trial to express. This does not, as one of our commentators put it, entail 'hiring George Clooney'196, but rather a recognition that explaining oneself to an audience beyond fellow jurists is part of the job. ${ }^{197}$

\section{B. The Audience}

As crucial as the authors sending the message, are those who are the subject of the expressivist potential of trials: the audience. The most important audience is the population of the society that was affected by the conflict — although one might hope that other societies get the messages expressed as well. They are-as it were-the ones who are to be transformed by the proceedings. However, the audience is not a uniform group, but rather consists of different groups with their own background, experience and allegiances. And since there is no single message being sent out of court, different stories will resonate with

\footnotetext{
${ }^{196}$ We wish to thank Daniele Archibugi for this provocative remark, which helped us to better formulate our intent.

197 See also Glasius, Marlies (2012). 'Do International Criminal Courts Require Democratic Legitimacy?', European Journal of International Law, 23(1) at 61-62 and 65 on this point.
} 
different groups. In the Karadžić case, many Serbs will see their worries and ideas confirmed in what Karadžić says in court, whereas more Croats or Bosniaks might hear the story of the prosecution. In combination with polarized post-conflict publics, the antagonistic nature of criminal trials poses a substantial challenge to realizing expressivist goals.

\section{The Stage}

International criminal courts are not institutions that can take their legitimacy for granted. The manner of their establishment always leaves space, although to different degrees, for an argument that they were imposed on a people, and hence lack democratic legitimacy. The requirement for democratic legitimacy of international criminal courts may be contested on many grounds in legal theory ${ }^{198}$, but such rhetoric may nonetheless be persuasive to broader audiences. Beyond this, for the ad hoc courts in particular, there may be further delegitimizing arguments relating the circumstances of the establishment of a court to the conflict in question, implying bias. As we have shown, prominent defendants can-and will- use the stage the court offers them not only to advance their own case, but also to advance a case against the court itself. If the defendant succeeds in delegitimizing the court in the eyes of (some of) the audiences - the entire expressivist potential towards those audiences will be undermined. If the court is not taken seriously, the reconciling effects, norm-dissemination and truth telling cannot succeed.

Although the competition of different narratives is to be expected (and perhaps essential) in a criminal trial, both defending another version of reality, it does pose a threat to expressivism. We have found that expressivism is likely to be hindered by the capacity of the defendant to provide an internally coherent alternative narrative about the crimes committed, about his role in it, and about the legitimacy of the proceedings itself. We also found that the actors were playing to different audiences. The prosecution was playing first and foremost to the bench, whereas the defendant appeared to be primarily addressing his

\footnotetext{
198 See Glasius (2012); Armin von Bogdandy and Ingo Venzke, 23 'In Whose Name? An Investigation of International Courts' Public Authority and Its Democratic Justification' European Journal of International Law, 1, 7-41; Aaron Fichtelberg, 'Democratic Legitimacy and the International Criminal Court: a Liberal Defence’, 4 J Int'l Criminal Justice (2006) 778.
} 
compatriots. Two other elements require further research: the audiences, and their reception of the narratives; and the stage, which unlike in domestic trials cannot be assumed to be uncontested, and itself becomes part of the subject matter of the play.

Further research on the elements of actors, audiences and stage in high-profile international criminal trials can provide further guidance on whether the obstacles to expressivism we identified can under certain circumstances be overcome, or whether they are structural features. One thing is clear though: the messages that the play called "Karadžić" at the Yugoslavia tribunal is conveying are far from unambiguous, and their expressivist effects cannot be taken for granted. 